OPEN ACCESS

Edited by:

Jiaojian Wang,

University of Electronic Science and Technology of China, China

Reviewed by:

Xiaojing Long,

Shenzhen Institutes of Advanced

Technology, Chinese Academy

of Sciences (CAS), China

Li Wang,

Beijing Institute of Technology, China

*Correspondence:

Shimin $\mathrm{Hu}$

583534035@qq.com

Chunyan Liu

Icy_e_mail@163.com

Specialty section:

This article was submitted to

Brain Imaging and Stimulation,

a section of the journal

Frontiers in Human Neuroscience

Received: 29 July 2021 Accepted: 06 September 2021 Published: 28 September 2021

Citation:

Zhang T, Pan N, Wang Y, Liu C and Hu S (2021) Transcranial

Focused Ultrasound Neuromodulation: A Review of the Excitatory and Inhibitory Effects on

Brain Activity in Human and Animals. Front. Hum. Neurosci. 15:749162. doi: 10.3389/fnhum.2021.749162

\section{Transcranial Focused Ultrasound Neuromodulation: A Review of the Excitatory and Inhibitory Effects on Brain Activity in Human and Animals}

\author{
Tingting Zhang ${ }^{1,2}$, Na Pan ${ }^{1,2}$, Yuping Wang ${ }^{1,2,3}$, Chunyan Liu${ }^{1,2 *}$ and Shimin $\mathrm{Hu}^{1,2 *}$ \\ 1 Department of Neurology, Xuanwu Hospital, Capital Medical University, Beijing, China, ${ }^{2}$ Beijing Key Laboratory \\ of Neuromodulation, Beijing, China, ${ }^{3}$ Center of Epilepsy, Institute of Sleep and Consciousness Disorders, Beijing Institute \\ for Brain Disorders, Capital Medical University, Beijing, China
}

Non-invasive neuromodulation technology is important for the treatment of brain diseases. The effects of focused ultrasound on neuronal activity have been investigated since the 1920s. Low intensity transcranial focused ultrasound (tFUS) can exert nondestructive mechanical pressure effects on cellular membranes and ion channels and has been shown to modulate the activity of peripheral nerves, spinal reflexes, the cortex, and even deep brain nuclei, such as the thalamus. It has obvious advantages in terms of security and spatial selectivity. This technology is considered to have broad application prospects in the treatment of neurodegenerative disorders and neuropsychiatric disorders. This review synthesizes animal and human research outcomes and offers an integrated description of the excitatory and inhibitory effects of tFUS in varying experimental and disease conditions.

Keywords: transcranial focused ultrasound, neuromodulation, non-invasive brain stimulation, human, animal

\section{INTRODUCTION}

Brain stimulation techniques have shown efficacy for ameliorating neurological and psychiatric disorders (Hoy and Fitzgerald, 2010). Invasive electrical brain stimulation modalities, such as vagus nerve stimulation (VNS) or deep brain stimulation (DBS), require the surgical placement of electrodes in the brain (Rahimpour et al., 2021; Wang Y. et al., 2021). The modulation effects of non-invasive strategies, such as transcranial direct current stimulation (tDCS) and repetitive transcranial magnetic stimulation (rTMS) are limited to the cortical surface (Hoy and Fitzgerald, 2010; Romanella et al., 2020). Transcranial focused ultrasound (tFUS) transmits lowintensity ultrasound into the brain non-invasively and focuses on deep brain regions. It is an emerging neuromodulation technology with the advantages of better spatial resolution and safety (Mehic et al., 2014).

The frequency of the ultrasound mechanical wave is higher than the range of human hearing $(>20 \mathrm{kHz}$ ). Ultrasound can be focused across solid structures and transmitted long distances with minimal power loss in soft biological tissues (Bystritsky et al., 2011). It has been the most widely used biomedical imaging modality for a long history. Ultrasound display different biological effect based on a different intensity. High-intensity $\left(>200 \mathrm{~W} / \mathrm{cm}^{2}\right)$ focused ultrasound induces permanent lesions through coagulation of cellular proteins and thermal ablation. It has been approved by the FDA for the treatment of tremors associated with Parkinson's disease and 
essential tremors. Medium intensity $\left(100-200 \mathrm{~W} / \mathrm{cm}^{2}\right)$ ultrasound has been used to break through the blood-brain barrier for drug delivery. Low-intensity $\left(<100 \mathrm{~W} / \mathrm{cm}^{2}\right)$ focused ultrasound is considered the main form of non-invasive neuromodulation (Kubanek, 2018).

Research on the potential clinical value of focused ultrasound as a neuromodulation method started half a century ago, with interest increasing dramatically over the past decade (Fini and Tyler, 2017). Studies using various parameters have shown that tFUS can modulate neural activity in the brains of animals and humans. It has the potential to modulate brain activities indicated by sensory or motor behaviors, functional magnetic resonance imaging (fMRI), electroencephalography (EEG), and near-infrared spectroscopy (NIRS) (Krishna et al., 2018; Legon et al., 2018b). The findings of in vitro and in vivo experiments have promoted the understanding of ultrasound neuromodulation. However, the high variability in experimental conditions, different ultrasound parameters, as well as partially conflicting results, led to contradictory interpretations. To achieve clinical application, it is important to clarify the excitatory and inhibitory effects of tFUS. In this review, we summarize the current findings of the brain modulatory effects of tFUS in both animal and human studies. We discussed findings of the excitatory or inhibitory effect of tFUS in light of varying experimental and disease conditions. Finally, the proposed mechanism for ultrasound neuromodulation was discussed.

\section{LITERATURE SEARCH}

We searched the literature in the databases of the PubMed /MEDLINE/EMBASE with the following research string, in March 2021: ("Low-intensity focused ultrasound[Title/Abstract]" OR "Transcranial focused ultrasound[Title/Abstract]") AND ("Neuromodulation[Title/Abstract]" OR "Brain Stimulation [Title/Abstract]"). Non-English language studies and duplicates were excluded. Studies were also excluded according to the following criteria: (1) Study investigating the diagnostic aspect of transcranial ultrasound rather than neuromodulation effects; (2) Study investigating the application of transcranial ultrasound in ablation neurosurgery or drug delivery; (3) Study focusing on the development of new ultrasound device; (4) Study published as the conference abstract without a full text, as dissertation or those published in books or only providing surrogate biomarkers. The resulting original articles that reported the use of tFUS in animals and human subjects to modulate brain activity were included (Tables 1, 2). Ultimately 41 studies were selected for discussion in this review, including 23 animals and 18 human studies.

\section{MAIN ULTRASOUND PARAMETERS}

The neuromodulation effect of ultrasound depends on the stimulation parameters used. Pulsed ultrasound is the main form of neuromodulation application to minimize the probability of tissue heating or damage. Fundamental frequency, pulse repetition frequency $(\mathrm{PRF})$, duty cycle (DC), sonication duration
(SD), and intensity are the five most important elements that define a sonication protocol. The fundamental frequency refers to the number of oscillatory cycles per unit time and is inversely proportional to wavelength. Fundamental frequency significantly affects the spatial targeting of brain regions. A higher fundamental frequency induces stimulation with a tighter focus (when the frequency is $>1 \mathrm{MHz}$, the diameter can be as narrow as few millimeters). But ultrasound with higher fundamental frequency has more transcranial attenuation and scattering. 200$650 \mathrm{kHz}$ have been used in most human and animal studies. PRF refers to the rate of the pulses delivered. DC is the proportion of each pulse filled with ultrasound cycles, which is an important parameter that determines the direction of the neuromodulation effect. SD refers to the total time from the onset of the first pulse to the termination of the last pulse, which may determine the total intensity and tissue heating. The combination of PRF, DC, and SD may affect the inhibition or excitation of cortical neurons. The intensity of acoustic exposure is commonly characterized by two parameters: the spatialpeak temporal average $\left(\mathrm{I}_{\text {spta }}\right)$ and the spatial-peak pulse average $\left(\mathrm{I}_{\text {sppa }}\right) . \mathrm{I}_{\text {spta }}$ measures the average intensity during the entire sonication therapy and is proportional to SD. $\mathrm{I}_{\text {sppa }}$ measures the average intensity of a single pulse and provides estimates of short-term mechanical biological effects. The mechanical index (MI) is an indicator of the risk of potentially destructive biomechanical effects on tissues, such as inertial cavitation. It is equal to the peak negative pressure divided by the square of the fundamental frequency. Considering that thermal and mechanical effects may cause brain damage, FDA guidelines for cephalic ultrasound suggest a maximum safety value range of Ispta $<94 \mathrm{~mW} / \mathrm{cm}^{2}$, Isppa $<190 \mathrm{~W} / \mathrm{cm}^{2}$, and $\mathrm{MI}<1.9$ to avoid cavitation and heating in humans (United States Food and Drug Administration. Marketing clearance of diagnostic ultrasound systems and transducers. Draft guidance for industry and food and drug administration staff. 2019).

\section{NEUROMODULATION EFFECTS IN ANIMALS}

To use ultrasound for neuromodulation therapy, an important issue is to clarify its excitatory or inhibitory effects on the central nervous system. We reviewed the reports of the neuromodulatory effects of ultrasound in animals. Studies have been conducted in mice, rats, ovines, swine, sheep, and macaques with different ultrasound parameters, and brain targets. The reported brain targets included the motor cortex, midbrain, somatosensory cortex, hypothalamus, right anterior cortex, hippocampus, thalamus, and visual cortex. The excitatory and inhibitory effects vary with the stimulation targets and sonication parameters (Table 1).

\section{EXCITATORY EFFECT}

Several studies have reported excitatory effects of tFUS targeting the cortex and deep brain areas. For targeting at 
TABLE 1 | tFUS neuromodulation studies in animals.

\begin{tabular}{|c|c|c|c|c|c|}
\hline References & Animal species & Targets & Sonication parameters & Key findings & Effect \\
\hline $\begin{array}{l}\text { Mohammadjavadi } \\
\text { et al. (2019) }\end{array}$ & Normal mice & Midbrain & $\begin{array}{l}\text { Focused, frequency }=500 \mathrm{kHz} \\
\mathrm{PRF}=1.5 \mathrm{kHz}, 8 \mathrm{kHz}\end{array}$ & $\begin{array}{l}\text { tFUS-evoked motor responses independent of } \\
\text { the peripheral auditory system; high correlation } \\
\text { between tFUS pulse duration and } \\
\text { electromyography response duration }\end{array}$ & Excitatory \\
\hline Yuan et al. (2020) & Normal mice & Motor cortex & $\begin{array}{l}\text { Unfocused, frequency }=500 \mathrm{kHz}, \mathrm{PRF}=1 \\
\mathrm{kHz}, \mathrm{SD}=400 \mathrm{~ms}, \mathrm{DC}=40 \% \\
\text { Isppa }=0.8 \mathrm{~W} / \mathrm{cm}^{2}\end{array}$ & $\begin{array}{l}\text { Ultrasound pulses induced motor response, } \\
\text { neural activity, and rapid hemodynamic } \\
\text { response selectively at the stimulation site }\end{array}$ & Excitatory \\
\hline Kim et al. (2014) & Normal rats & Somatomotor area & $\begin{array}{l}\text { Focused, frequency }=350 \mathrm{kHz} \text { and } \\
650 \mathrm{~Hz}, \mathrm{DC}=30-100 \% \\
\mathrm{PRF}=0.1-2.8 \mathrm{kHz}, \mathrm{SD}=150-400 \mathrm{~ms} \\
\mathrm{TBD}=0.25-5 \mathrm{~ms}\end{array}$ & $\begin{array}{l}1-5 \mathrm{~ms} \text { TBD, } 50 \% \text { DC, } 300 \mathrm{~ms} \text { SD stimulates } \\
\text { the somatomotor area most effectively; } 350 \mathrm{kHz} \\
\text { frequency outperforms } 650 \mathrm{kHz} \text {; pulsed } \\
\text { outperforms the equivalent continuous } \\
\text { sonication }\end{array}$ & Excitatory \\
\hline Yu et al. (2016) & Normal rats & Right anterior cortex & $\begin{array}{l}\text { Focused, frequency }=500 \mathrm{kHz} \\
\mathrm{PRF}=2.0 \mathrm{kHz}, \text { Isppa }=0.74-4.6 \mathrm{~mW} / \mathrm{cm}^{2}\end{array}$ & $\begin{array}{l}\text { Low-intensity tFUS activated neurons correlated } \\
\text { to intensity and SD. tFUS stimulation activated } \\
\text { the focal site and propagating to surrounding } \\
\text { areas over time }\end{array}$ & Excitatory \\
\hline Moore et al. (2015) & Normal mice & $\begin{array}{l}\text { Somatosensory } \\
\text { barrel cortex }\end{array}$ & $\begin{array}{l}\text { Focused, frequency }=350 \mathrm{kHz} \\
\mathrm{DC}=42.8 \%, \mathrm{PRF}=2.0 \mathrm{kHz} \\
\mathrm{TBD}=0.5 \mathrm{~ms}\end{array}$ & $\begin{array}{l}\text { Ultrasound stimulation induced depolarition of } \\
\text { pyramidal cells }\end{array}$ & Excitatory \\
\hline $\begin{array}{l}\text { Fisher and } \\
\text { Gumenchuk (2018) }\end{array}$ & Normal mice & $\begin{array}{l}\text { Primary } \\
\text { somatosensory } \\
\text { cortex }\end{array}$ & $\begin{array}{l}\text { Focused, } \\
\text { frequency }=510 \mathrm{kHz}, \mathrm{PRF}=1 \mathrm{kHz} \text {, } \\
\text { Isppa }=0.69 \text { or } 3.5 \mathrm{~W} / \mathrm{cm}^{2}\end{array}$ & $\begin{array}{l}\text { Low-intensity FUS alters both the kinetics and } \\
\text { spatial patterns of neural activity }\end{array}$ & Excitatory \\
\hline Yoo et al. (2011) & Normal rats & Thalamus & $\begin{array}{l}\text { Focused, frequency }=440-700 \mathrm{KHz}, \\
\mathrm{PRF}=100 \mathrm{~Hz}, \mathrm{TBD}=0.5 \mathrm{~ms}, \mathrm{DC}=50 \%, \\
\text { Isppa }=3.3-6 \mathrm{~W} / \mathrm{cm}^{2}\end{array}$ & $\begin{array}{l}\text { Ultrasound stimulation reduced the time to } \\
\text { emergence from ketamine/xylazine anesthesia in } \\
\text { rats }\end{array}$ & Excitatory \\
\hline Baek et al. (2018) & Stroke mice & $\begin{array}{l}\text { Lateral cerebellar } \\
\text { nucleus }\end{array}$ & $\begin{array}{l}\text { Focused, frequency }=350 \mathrm{kHz} \mathrm{DC}=50 \%, \\
\mathrm{PRF}=1 \mathrm{kHz}, \mathrm{TBD}=0.5 \mathrm{~ms}, \mathrm{SD}=300 \mathrm{~ms}, \\
\text { Isppa }=2.54 \mathrm{~W} / \mathrm{cm}^{2}\end{array}$ & $\begin{array}{l}\text { tFUS enhanced the sensorimotor performance } \\
\text { in mice of photothrombotic stroke }\end{array}$ & Excitatory \\
\hline Lee et al. (2018) & Normal rats & Motor cortex & $\begin{array}{l}\text { Focused, frequency }=600 \mathrm{kHz} \\
\mathrm{PRF}=500 \mathrm{~Hz}, \mathrm{TBD}=1 \mathrm{~ms}, \mathrm{DC}=50 \% \\
\text { Isppa }=8.8 \mathrm{~W} / \mathrm{cm}^{2}, 14.9 \mathrm{~W} / \mathrm{cm}^{2}\end{array}$ & $\begin{array}{l}\text { Wearable miniature stimulator applied tFUS and } \\
\text { elicited movements in both awake and } \\
\text { anesthetized rats }\end{array}$ & Excitatory \\
\hline Li et al. (2019) & Normal mice & $\begin{array}{l}\text { Somatosensory } \\
\text { cortex }\end{array}$ & $\begin{array}{l}\text { Focused, frequency }=2 \mathrm{MHz}, \mathrm{PRF}=1 \mathrm{kHz} \\
\mathrm{DC}=30 \%, \mathrm{SD}=300 \mathrm{~ms}\end{array}$ & $\begin{array}{l}\text { Wearable ultrasound stimulator induced action } \\
\text { potentials and evoked sonication-related } \\
\text { movement behaviors }\end{array}$ & Excitatory \\
\hline Darrow et al. (2019) & Normal rats & Thalamus & $\begin{array}{l}\text { Focused,frequency }=3.2 \mathrm{MHz} \\
\mathrm{PRF}=500 \mathrm{~Hz}, \mathrm{DC}=5-70 \% \\
\text { Ispta }=0.01-36.03 \mathrm{~W} / \mathrm{cm}^{2}\end{array}$ & $\begin{array}{l}\text { tFUS suppressed a primary sensory pathway, } \\
\text { much of the suppression could be attributed to } \\
\text { thermal neuromodulation }\end{array}$ & Inhibitory \\
\hline $\begin{array}{l}\text { Dallapiazza et al. } \\
\text { (2018) }\end{array}$ & Swine & Thalamus & $\begin{array}{l}\text { Focused, } \\
\text { Frequency = } 1.145 \mathrm{MHz}, 650 \mathrm{kHz} \text {, } \\
220 \mathrm{kHz}, \mathrm{DC}=43.7 \%, \mathrm{Isppa}=25-30 \\
\mathrm{~W} / \mathrm{cm}^{2}\end{array}$ & $\begin{array}{l}\text { Low intensity focused ultrasound inhibited } \\
\text { sensory evoked potentials with a spatial } \\
\text { resolution } \sim 2 \mathrm{~mm} \text {. }\end{array}$ & Inhibitory \\
\hline Min et al. (2011) & $\begin{array}{l}\text { PTZ-injected } \\
\text { epilepsy rats }\end{array}$ & Thalamus & $\begin{array}{l}\text { Focused, frequency }=690 \mathrm{kH} \\
\mathrm{TBD}=0.25-5 \mathrm{~ms}, \mathrm{PRF}=100 \mathrm{~Hz} \\
\mathrm{DC}=5 \%, \mathrm{Isppa}=130 \mathrm{~mW} / \mathrm{cm}^{2}\end{array}$ & $\begin{array}{l}\text { tFUS decreased epileptic EEG bursts and the } \\
\text { epileptic behavior, did not cause any damage to } \\
\text { the brain tissue }\end{array}$ & Inhibitory \\
\hline Yang et al. (2020) & TLE mice & Hippocampus & $\begin{array}{l}\text { Focused, frequency }=500 \mathrm{kHz} \text {, for } \\
\text { modulation of the neural oscillation: } \\
\mathrm{PRF}=1 \mathrm{kHz}, \mathrm{SD}=400 \mathrm{~ms}, \mathrm{DC}=40 \% \text {; for } \\
\text { seizure inhibition: frequency }=500 \mathrm{kHz} \text {, } \\
P R F=500 \mathrm{~Hz}, \mathrm{SD}=30 \mathrm{~s} \text {, and } \mathrm{DC}=5 \%\end{array}$ & $\begin{array}{l}\text { The ultrasound modulated the neural oscillation } \\
\text { and inhibit the seizure in TLE mice }\end{array}$ & Inhibitory \\
\hline Chen et al. (2020) & $\begin{array}{l}\text { PTZ-injected } \\
\text { epilepsy rats }\end{array}$ & $\begin{array}{l}\text { Cortex or } \\
\text { hippocampus area }\end{array}$ & $\begin{array}{l}\text { Focused, frequency }=0.5 \mathrm{MHz} \text {, various } \\
\text { sonication parameters }\end{array}$ & $\begin{array}{l}\text { Pulsed FUS exposure suppressed epileptic } \\
\text { spikes and affected the PI3K-Akt-mTOR } \\
\text { pathway }\end{array}$ & Inhibitory \\
\hline Lin et al. (2020) & $\begin{array}{l}\text { Macaques model of } \\
\text { epilepsy, tissues } \\
\text { from patients with } \\
\text { TLE }\end{array}$ & Right frontal lobe & $\begin{array}{l}\text { Focused, frequency }=750 \mathrm{kHz} \\
\text { Isppa }=2.02 \mathrm{~W} / \mathrm{cm}^{2}, \mathrm{PRF}=1 \mathrm{kHz} \\
\mathrm{TBD}=0.3 \mathrm{~ms}, \mathrm{SD}=200 \mathrm{~ms}\end{array}$ & $\begin{array}{l}\text { tFUS reduces epileptiform activities and } \\
\text { behavioral seizures in epileptic monkeys, inhibits } \\
\text { the epileptiform discharges in neurons from } \\
\text { patients, activates the inhibitory interneurons }\end{array}$ & Inhibitory \\
\hline Kim et al. (2015) & Normal rats & Visual cortex & $\begin{array}{l}350 \mathrm{kHz}, \mathrm{PRF}=100 \mathrm{~Hz}, \text { Isppa }=1,3 \\
5 \mathrm{~W} / \mathrm{cm}^{2}, \mathrm{DC}=1,5,8.3 \%\end{array}$ & $\begin{array}{l}5 \% \text { DC: VEPs magnitude decreased by tFUS } \\
\text { with } 3 \mathrm{~W} / \mathrm{cm}^{2} \text { Isppa, but not } 1 \mathrm{~W} / \mathrm{cm}^{2} \text {, slightly } \\
\text { elevated when use } 5 \mathrm{~W} / \mathrm{cm}^{2} \text { Isppa; } 3 \mathrm{~W} / \mathrm{cm}^{2} \\
\text { Isppa: VEPs magnitude decreased by tFUS with } \\
5 \% \text { DC, but not } 1 \% \text { DC, slightly elevated when } \\
\text { use } 8.3 \% \text { DC }\end{array}$ & Inhibitory \\
\hline Yoon et al. (2019) & Ovine & $\begin{array}{l}\text { Primary } \\
\text { sensorimotor area } \\
\text { and its thalamic } \\
\text { projection }\end{array}$ & $\begin{array}{l}\text { Focused, frequency }=250 \mathrm{kHz} \text {; Excitatory } \\
\text { effects: } \mathrm{DC}=30,50,70,100 \% \\
\text { PRF }=100-1400 \mathrm{~Hz}, \mathrm{TBD}=0.5-3 \mathrm{~ms}, \\
\text { Isppa }=15.8,18.2 \mathrm{~W} / \mathrm{cm}^{2} . \text { Inhibitory } \\
\text { effects: } \mathrm{DC}=3,5 \%, \mathrm{PRF}=30-100 \mathrm{~Hz}, \\
\text { TBD }=0.5,1.0 \mathrm{~ms}, \text { Isppa }=5.4 \\
11.6 \mathrm{~W} / \mathrm{cm}^{2}\end{array}$ & $\begin{array}{l}\text { tFUS with } 70 \% \text { DC showed superior stimulation } \\
\text { efficiency and } 0.5 \text { ms TBD resulted in the } \\
\text { highest response rate. The modulatory effects } \\
\text { were transient and reversible. Repeated } \\
\text { exposure to tFUS did not damage the brain } \\
\text { tissue }\end{array}$ & $\begin{array}{l}\text { Excitatory } \\
\text { from EMG } \\
\text { and inhibitory } \\
\text { from SEPs }\end{array}$ \\
\hline Verhagen et al. (2019) & Macaque & SMA, FPC & $\begin{array}{l}\text { Focused, frequency }=250 \mathrm{kHz} \\
\mathrm{PRF}=10 \mathrm{~Hz}, \mathrm{DC}=30 \%, \mathrm{PD}=30 \mathrm{~ms}, \\
\mathrm{Isppa}=24.1 \mathrm{~W} / \mathrm{cm}^{2} \text { for } \mathrm{SMA} \text { and } \\
31.7 \mathrm{~W} / \mathrm{cm}^{2} \text { for FPC }\end{array}$ & $\begin{array}{l}\text { tFUS changed each area's connectional } \\
\text { fingerprint, enhanced the connectivity activity in } \\
\text { proximal areas, reduced coupling between the } \\
\text { stimulated area and less closed regions. The } \\
\text { effects were temporary and not associated with } \\
\text { microstructural changes. }\end{array}$ & $\begin{array}{l}\text { Change the } \\
\text { connectional } \\
\text { fingerprint }\end{array}$ \\
\hline
\end{tabular}


TABLE 1 | (Continued)

\begin{tabular}{|c|c|c|c|c|c|}
\hline References & Animal species & Targets & Sonication parameters & Key findings & Effect \\
\hline Folloni et al. (2019) & Macaque & Amygdala, ACC & $\begin{array}{l}\text { Focused, frequency }=250 \mathrm{kHz} \\
\mathrm{DC}=30 \%, \text { Isppa }=64.9 \mathrm{~W} / \mathrm{cm}^{2} \text { in the } \\
\text { amygdala and } 18.8 \mathrm{~W} / \mathrm{cm}^{2} \text { in } \mathrm{ACC}\end{array}$ & $\begin{array}{l}\text { tFUS transiently and reversibly altered neural } \\
\text { activity in subcortical and deep cortical areas } \\
\text { with high spatial specificity; reduced the } \\
\text { interconnection of the targeted areas with other } \\
\text { regions. }\end{array}$ & $\begin{array}{l}\text { Decreased } \\
\text { network } \\
\text { connectivity }\end{array}$ \\
\hline $\begin{array}{l}\text { Fouragnan et al. } \\
\text { (2019) }\end{array}$ & Macaque & ACC & $\begin{array}{l}\text { Focused, frequency }=250 \mathrm{kHz} \\
\mathrm{PRF}=10 \mathrm{~Hz}, \mathrm{DC}=30 \%, \mathrm{PD}=30 \mathrm{~ms}\end{array}$ & $\begin{array}{l}\text { tFUS significantly changed ACC activity, altered } \\
\text { strength of connectivity from ACC with } 3 \text { other } \\
\text { regions, impaired translation of counterfactual } \\
\text { choice values into actual behavioral change }\end{array}$ & $\begin{array}{l}\text { Changed } \\
\text { connectivity map }\end{array}$ \\
\hline Wattiez et al. (2017) & Macaques & Visual cortex & $\begin{array}{l}\text { Frequency }=320 \mathrm{kHz} \text {, Isppa }=5.6,1.9 \\
\mathrm{~W} / \mathrm{cm}^{2}\end{array}$ & $\begin{array}{l}\text { tFUS changed } 40 \% \text { of neurons in the recorded } \\
\text { region, half showed a transient increase of } \\
\text { activity and half showed decrease of activity. }\end{array}$ & $\begin{array}{l}\text { Different neurons } \\
\text { respond } \\
\text { differently }\end{array}$ \\
\hline Yang et al. (2021) & Macaque & $\begin{array}{l}\text { Somatosensory } \\
\text { areas } 3 a / 3 b\end{array}$ & $\begin{array}{l}\text { Focused, frequency }=250 \mathrm{kHz} \\
\mathrm{DC}=50 \%, \mathrm{PRF}=2 \mathrm{kHz} \\
\mathrm{Isppa}=2.0 \mathrm{~W} / \mathrm{cm}^{2}\end{array}$ & $\begin{array}{l}\text { tFUS suppressed tactile stimulus-evoked fMRI } \\
\text { responses, directly activated neurons within the } \\
\text { target at resting state }\end{array}$ & $\begin{array}{l}\text { Neuron } \\
\text { state-dependent } \\
\text { effect }\end{array}$ \\
\hline
\end{tabular}

$\overline{A C C}$, anterior cingulate cortex; DC, duty cycle; FPC, frontal polar cortex; Isppa, the intensity of spatial-peak pulse average; PRF, pulse repetition frequency; SD, sonication

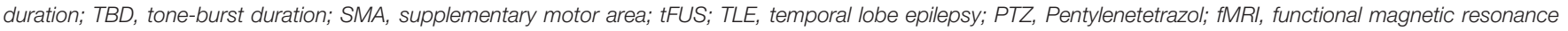
imaging; VEPS, visual evoked potentials; EEG, electroencephalography; EMG, electromyography; SEPS, somatosensory evoked potentials.

the motor cortex, unfocused ultrasound with a frequency of $500 \mathrm{kHz}$ evokes motor responses, and the responses are not related to the stimulation of the peripheral auditory system, which emphasizes the direct action of motor neurons in the brain (Mohammadjavadi et al., 2019). Another study used low-intensity tFUS $(500 \mathrm{kHz})$ to stimulate mouse motor cortical regions and demonstrated that tFUS induced tail movement, neural activity, and hemodynamic responses (cortical blood flow, CBF) immediately and returned to baseline at $\sim 5.5 \mathrm{~s}$. The relationships between $\mathrm{CBF}$ and key ultrasound parameters showed that the $\mathrm{CBF}$ responses increasing with increasing intensities (Isppa $=0.2-1.1 \mathrm{~W} / \mathrm{cm}^{2}, \mathrm{SD}=400 \mathrm{~ms}, \mathrm{DC}=40 \%$ ) and SD (SD $=50-400 \mathrm{~ms}$, Isppa $\left.=0.8 \mathrm{~W} / \mathrm{cm}^{2}, \mathrm{DC}=40 \%\right)$, while had a weak dependence on DC (DC $=10-40 \%, S D=50-$ $400 \mathrm{~ms}$, Isppa $=0.8 \mathrm{~W} / \mathrm{cm}^{2}$ ) (Yuan et al., 2020). Kim et al. (2014) examined the stimulation effects of tFUS with a range of sonication parameters administrated to the somatomotor cortex of rats in vivo. Based on comparison experiments, the authors found that $50 \%$ of DC outperforms 30 and $70 \%$. Operating at $50 \% \mathrm{DC}$, the use of TBDs in the range of $1-5 \mathrm{~ms}$, serving as an effective pulsing scheme, $350 \mathrm{kHz}$ fundamental frequency outperforms $650 \mathrm{kHz}$, pulsed tFUS outperforms equivalent continuous sonication stimulate the target cortex most effectively. Further, for the parameter of SD, they found that $400 \mathrm{~ms}$ required higher Isppa for eliciting motor activity than 300 $\mathrm{ms}$, which may indicate that the longer SD might have recruited inhibitory neural circuits or neural cells. Overall, this study found non-linear neural responses to tFUS that might include the activation of motor neurons and inhibitory interneurons (Kim et al., 2014).

For other cortex regions, Yu et al. (2016) demonstrated that low intensity (Ispta $<1 \mathrm{Mw} / \mathrm{cm}^{2}$ ) $500 \mathrm{kHz}$ pulsed tFUS targeting the right anterior cortex of rats evoked time-locked activation of the brain, as correlated to intensity and SD. They also suggested electrophysiological source imaging as a useful tool to quantify tFUS effects, guide its use for neuromodulation (Yu et al., 2016). The study of Moore et al. (2015) recorded local field potential fluctuations in the motor cortex in response to ultrasound stimulation of the mouse somatosensory barrel cortex. Ultrasound stimulation at $350 \mathrm{kHz}$ and $42.8 \% \mathrm{DC}$ induced depolarization of cerebral cortical pyramidal neurons, which indicates an excitatory effect of nerve transmission (Moore et al., 2015). Fisher and Gumenchuk (2018) demonstrated that tFUS with a frequency of $510 \mathrm{kHz}$ reduced the latency and concentrates the spatial patterns of neural activity in the primary somatosensory cortex. The findings suggest the using of tFUS to target and alter spatial aspects of sensory receptive fields on the cerebral cortex (Fisher and Gumenchuk, 2018). As for deep brain targets, the research of Yoo et al. (2011) revealed that pulsed FUS targeting at the thalamus significantly decreased the time to emergence from ketamine/xylazine anesthesia in rats. This study provided early evidence for the excitatory neuromodulatory potential of tFUS targeting the deep brain area (Yoo et al., 2011). The study of Baek et al. (2018) provides the first evidence in the disease model showing that tFUS-induced cerebellar modulation improved impaired sensorimotor function in stroke mice and could be a potential strategy for post stroke recovery. They hypothesized that the effectiveness could be attributable to long-term potentiation of hypoactive neural connections between the motor cortex and deep cerebellar nucleus induced by tFUS. Longer follow-up studies are necessary to fully confirm the effects of tFUS on post stroke recovery (Baek et al., 2018).

\section{INHIBITORY EFFECT}

Three studies targeting the thalamus showed inhibitory effects of tFUS. The study of Darrow et al. (2019) revealed that 3.2 $\mathrm{MHz}$ tFUS targeting the rat thalamus reversibly suppressed somatosensory evoked potentials (SEPs) in a spatially and intensity-dependent manner. The effect was independent of the parameters of DC, peak pressure, or modulation frequency. The ultrasound frequency used in this study is higher than most other studies, which may cause an obvious thermal effect and lead to the suppression effect (Darrow et al., 2019). The study of Dallapiazza et al. (2018) demonstrated that low-intensity focused ultrasound with frequencies of $1.1 \mathrm{MHz}, 220 \mathrm{kHz}$, 
TABLE 2 | tFUS neuromodulation studies in human.

\begin{tabular}{|c|c|c|c|c|c|c|c|}
\hline References & $\begin{array}{l}\text { Subjects/study } \\
\text { design }\end{array}$ & Targets & Sonication parameters & indexes & Key findings & $\begin{array}{l}\text { Modulate } \\
\text { effects }\end{array}$ & $\begin{array}{l}\text { Adverse } \\
\text { effects }\end{array}$ \\
\hline $\begin{array}{l}\text { Lee et al. } \\
(2015)\end{array}$ & $\begin{array}{l}\text { Healthy volunteers } \\
(n=1) / \text { within- } \\
\text { subjects, sham- } \\
\text { controlled study }\end{array}$ & S1 (hand) & $\begin{array}{l}\text { Focused, } \\
\text { frequency }=250 \mathrm{kHz}, \\
\text { PRF }=500 \mathrm{~Hz}, \\
\mathrm{TBD}=1 \mathrm{~ms}, \mathrm{DC}=50 \%, \\
\mathrm{SD}=300 \mathrm{~ms}, \\
\text { Isppa }=3 \mathrm{~W} / \mathrm{cm}^{2}\end{array}$ & $\begin{array}{l}\text { EEG, fMRI, tactile } \\
\text { sensations task }\end{array}$ & $\begin{array}{l}\text { tFUS elicited transient } \\
\text { tactile sensations } \\
\text { accurately to one finger, } \\
\text { evoked cortical } \\
\text { potentials similar to the } \\
\text { SEPs generated by MN } \\
\text { stimulation. }\end{array}$ & Excitatory & No \\
\hline $\begin{array}{l}\text { Lee et al. } \\
\text { (2016a) }\end{array}$ & $\begin{array}{l}\text { Healthy volunteers } \\
(n=10) / \text { within- } \\
\text { subjects, double- } \\
\text { blind, sham- } \\
\text { controlled study }\end{array}$ & $\mathrm{S} 1$ and S2 & $\begin{array}{l}\text { Focused, } \\
\text { frequency }=210 \mathrm{kHz}, \\
\mathrm{PRF}=500 \mathrm{~Hz}, \\
\mathrm{PD}=1 \mathrm{~ms}, \mathrm{DC}=50 \%, \\
\mathrm{SD}=500 \mathrm{~ms}, \\
\text { Isppa }=7.0-8.8 \mathrm{~W} / \mathrm{cm}^{2}\end{array}$ & $\begin{array}{l}\text { fMRI, EEG, tactile } \\
\text { sensory task }\end{array}$ & $\begin{array}{l}\text { tFUS targeting at S1 and } \\
\text { S2 separately or } \\
\text { simultaneously, elicited } \\
\text { tactile sensations from } \\
\text { the contralateral } \\
\text { hand/arm areas }\end{array}$ & Excitatory & No \\
\hline $\begin{array}{l}\text { Gibson et al. } \\
\text { (2018) }\end{array}$ & $\begin{array}{l}\text { Healthy volunteers } \\
(n=40) / \text { between- } \\
\text { subjects, single- } \\
\text { blind, sham- } \\
\text { controlled study }\end{array}$ & M1 & $\begin{array}{l}\text { Unfocused, Continuous, } \\
\text { frequency }=2.32 \mathrm{MHz} \text {, } \\
\text { Isppa }=34.96 \mathrm{~W} / \mathrm{cm}^{2}\end{array}$ & TMS-induced MEPs & $\begin{array}{l}\text { Ultrasound increased } \\
\text { MEPs amplitude: } 33.7 \% \\
\text { at } 1 \mathrm{~min}, 32.2 \% \text { at } 6 \mathrm{~min} \\
\text { post stimulation) }\end{array}$ & Excitatory & No \\
\hline Ai et al. (2018) & $\begin{array}{l}\text { Healthy volunteers } \\
(n=6) / \text { Pre-post } \\
\text { interventional study }\end{array}$ & $\begin{array}{l}\text { Primary } \\
\text { sensorimotor } \\
\text { cortex } \\
\text { (caudate area) }\end{array}$ & $\begin{array}{l}\text { Focused, } \\
\text { frequency }=500 \mathrm{kHz} \text {, } \\
\mathrm{PRF}=1 \mathrm{kHz}, \mathrm{DC}=36 \% \text { in } \\
\text { 3T MRI experiment; } \\
\text { frequency = } 860 \mathrm{kHz} \text {, } \\
\mathrm{PRF}=0.5 \mathrm{kHz}, \mathrm{DC}=50 \% \\
\text { in } 7 \mathrm{~T} \text { MRI experiment; } \\
\mathrm{SD}=500 \mathrm{~ms}, \text { Isppa: } 6 \\
\mathrm{~W} / \mathrm{cm}^{2}\end{array}$ & $\begin{array}{l}\text { fMRI scan (cortical } \\
\text { BOLD at } 3 T \text { and } \\
\text { sub-cortical BOLD } \\
\text { at } 7 T \text { ) }\end{array}$ & $\begin{array}{l}\text { BOLD response was } \\
\text { detected in the } \mathrm{S} 1 \text { in the } \\
\text { 3T studies and in the } \\
\text { caudate in the } 7 \mathrm{~T} \text { study }\end{array}$ & Excitatory & $\begin{array}{l}\text { Not } \\
\text { available }\end{array}$ \\
\hline $\begin{array}{l}\text { Legon et al. } \\
\text { (2014) }\end{array}$ & $\begin{array}{l}\text { Healthy volunteers } \\
(n=30 \text { totally in } 3 \\
\text { exp)/within- } \\
\text { subjects, sham- } \\
\text { controlled study }\end{array}$ & $\mathrm{CP} 3$ & $\begin{array}{l}\text { Focused, } \\
\text { frequency = } 500 \mathrm{kHz}, \\
\mathrm{SD}=500 \mathrm{~ms} ; \\
\mathrm{PRF}=1 \mathrm{kHz} ; \mathrm{DC}=36 \%, \\
\text { Isppa = } 23.87 \mathrm{~W} / \mathrm{cm}^{2}\end{array}$ & $\begin{array}{l}\text { EEG activity } \\
\text { recorded from four } \\
\text { electrodes } \\
\text { surrounding CP3 } \\
\text { (C3, CP1, CP5 and } \\
\text { P3); SEPs induced } \\
\text { by MN stimulation; } \\
\text { two-point } \\
\text { discrimination tasks }\end{array}$ & $\begin{array}{l}\text { tFUS spatially attenuated } \\
\text { the amplitudes of SEPs, } \\
\text { modulated the spectral } \\
\text { content of } \\
\text { sensory-evoked brain } \\
\text { oscillations, enhanced } \\
\text { the somatosensory } \\
\text { discrimination abilities. }\end{array}$ & Inhibitory & $\begin{array}{l}\text { No } \\
\text { thermal or } \\
\text { mechanical } \\
\text { sensations }\end{array}$ \\
\hline $\begin{array}{l}\text { Mueller et al. } \\
\text { (2014) }\end{array}$ & $\begin{array}{l}\text { Healthy volunteers } \\
(n=25) / \text { within- } \\
\text { subjects, sham- } \\
\text { controlled study }\end{array}$ & $\begin{array}{l}\mathrm{CP} 3 \text { and } 1 \mathrm{~cm} \\
\text { laterally }\end{array}$ & $\begin{array}{l}\text { Focused, } \\
\text { frequency = 500 kHz, } \\
P D=0.36 \mathrm{~ms} ; \\
P R F=1 \mathrm{kHz}, \mathrm{DC}=36 \% ; \\
\mathrm{SD}=500 \mathrm{~ms}, \\
\text { Isppa }=23.87 \mathrm{~W} / \mathrm{cm}^{2}\end{array}$ & $\begin{array}{l}\text { EEG data were } \\
\text { acquired at sites C3, } \\
\text { CP1, CP5, and P3; } \\
\text { SEPs induced by } \\
\text { MN stimulation }\end{array}$ & $\begin{array}{l}\text { tFUS altered the phase } \\
\text { distribution of intrinsic } \\
\text { brain activity for beta } \\
\text { frequencies, changed } \\
\text { the phase rate of beta } \\
\text { and gamma frequencies, } \\
\text { affected phase } \\
\text { distributions in the beta } \\
\text { band of early SEPs }\end{array}$ & Inhibitory & $\begin{array}{l}\text { Not } \\
\text { available }\end{array}$ \\
\hline
\end{tabular}


TABLE 2 | (Continued)

\begin{tabular}{|c|c|c|c|c|c|c|c|}
\hline References & $\begin{array}{l}\text { Subjects/study } \\
\text { design }\end{array}$ & Targets & Sonication parameters & indexes & Key findings & $\begin{array}{l}\text { Modulate } \\
\text { effects }\end{array}$ & $\begin{array}{l}\text { Adverse } \\
\text { effects }\end{array}$ \\
\hline & & & & & components. & & \\
\hline $\begin{array}{l}\text { Legon et al. } \\
(2018 a)\end{array}$ & $\begin{array}{l}\text { Healthy volunteers } \\
(n=40) / \text { within- } \\
\text { subjects, sham- } \\
\text { controlled study }\end{array}$ & $\begin{array}{l}\text { Unilateral } \\
\text { sensory nuclei } \\
\text { of thalamus }\end{array}$ & $\begin{array}{l}\text { Focused, } \\
\text { frequency = } 500 \mathrm{kHz} ; \\
\mathrm{PD}=0.36 \mathrm{~ms} ; \\
\mathrm{PRF}=1 \mathrm{kHz} \text {; DC = 36\%; } \\
\text { Isppa: } 7.03 \mathrm{~W} / \mathrm{cm}^{2}\end{array}$ & $\begin{array}{l}\text { EEG, SEPs induced } \\
\text { by MN stimulation, } \\
\text { two-point } \\
\text { discrimination tasks }\end{array}$ & $\begin{array}{l}\text { FUS inhibited the } \\
\text { amplitude of the P14 } \\
\text { SEPs, attenuated alpha } \\
\text { and beta power, inhibited } \\
\text { the locked gamma } \\
\text { power, decreased the } \\
\text { performance in tactile } \\
\text { judgment task }\end{array}$ & Inhibitory & Not available \\
\hline $\begin{array}{l}\text { Legon et al. } \\
(2018 b)\end{array}$ & $\begin{array}{l}\text { Healthy volunteers } \\
(n=50) / \text { within- } \\
\text { subjects, sham- } \\
\text { controlled study }\end{array}$ & M1 & $\begin{array}{l}\text { Focused, } \\
\text { frequency = } 500 \mathrm{kHz} \\
\mathrm{PD}=0.36 \mathrm{~ms} ; \\
\mathrm{PRF}=1 \mathrm{kHz} ; \mathrm{DC}=36 \% \\
\mathrm{SD}=500 \mathrm{~ms} \\
\text { Isppa }=17.12 \mathrm{~W} / \mathrm{cm}^{2}\end{array}$ & $\begin{array}{l}\text { Recruitment curves, } \\
\text { MEPs, SICI, ICF, } \\
\text { stimulus response } \\
\text { reaction time task }\end{array}$ & $\begin{array}{l}\text { tFUS inhibited the } \\
\text { amplitude of MEPs, } \\
\text { attenuated ICF, reduced } \\
\text { reaction time in a motor } \\
\text { task. }\end{array}$ & Inhibitory & $\begin{array}{l}\text { Mild and } \\
\text { moderate } \\
\text { neck pain, } \\
\text { sleepiness, } \\
\text { muscle } \\
\text { twitches, } \\
\text { itchiness } \\
\text { and } \\
\text { headache. }\end{array}$ \\
\hline $\begin{array}{l}\text { Fomenko } \\
\text { et al. (2020) }\end{array}$ & $\begin{array}{l}\text { Healthy subjects } \\
(n=16) / \text { double- } \\
\text { blinded } \\
\text { study }\end{array}$ & M1 & $\begin{array}{l}\text { Annular ultrasound, } \\
\text { frequency }=500 \mathrm{kHz} \\
\mathrm{PRF}=1,000 \mathrm{~Hz} \\
\mathrm{SD}=0.1-0.5 \mathrm{~s} \\
\mathrm{DC}=10 / 30 / 50 \%, \mathrm{lsp} \\
\text { ta }=0.93 / 2.78 / 4.63 \mathrm{~W} / \mathrm{cm}^{2}\end{array}$ & $\begin{array}{l}\text { TMS-induced resting } \\
\text { peak-to-peak MEPs, } \\
\text { visuomotor task }\end{array}$ & $\begin{array}{l}\text { Ultrasound dose } \\
\text { dependently suppressed } \\
\text { TMS-elicited MEPs, } \\
\text { increased GABAA- } \\
\text { mediated SICI and } \\
\text { decreased reaction time } \\
\text { on visuomotor task }\end{array}$ & Inhibitory & No \\
\hline $\begin{array}{l}\text { Sanguinetti } \\
\text { et al. (2020) }\end{array}$ & $\begin{array}{l}\text { Healthy subjects } \\
(n=50) / \text { randomized, } \\
\text { placebo-controlled, } \\
\text { double-blind study }\end{array}$ & $\mathrm{rlFG}$ & $\begin{array}{l}\text { Focused, } \\
\text { frequency }=500 \mathrm{kHz} \\
\mathrm{PD}=65 \mu \mathrm{s}, \mathrm{PRF}=40 \mathrm{~Hz} \\
\mathrm{DC}=0.26 \%, \mathrm{SD}=30 \mathrm{~s} \\
\text { Ispta }=130 \mathrm{~mW} / \mathrm{cm}^{2}\end{array}$ & $\begin{array}{l}\text { Mood questionnaires } \\
\text { and EEG, fMRI and } \\
\text { resting-state } \\
\text { functional } \\
\text { connectivity }\end{array}$ & $\begin{array}{l}\text { 30-s tFUS induced } \\
\text { positive mood effects for } \\
\text { up to } 30 \text { min, } 2 \text { min of } \\
\text { tFUS modulated } \\
\text { functional connectivity } \\
\text { related to the rIFG and } \\
\text { DMN }\end{array}$ & Unknown & Not available \\
\hline $\begin{array}{l}\text { Hameroff } \\
\text { et al. (2013) }\end{array}$ & $\begin{array}{l}\text { Chronic pain } \\
(n=31) / \text { double } \\
\text { blind, sham- } \\
\text { controlled, crossover } \\
\text { study }\end{array}$ & $\begin{array}{l}\text { Posterior } \\
\text { frontal cortex, } \\
\text { contralateral } \\
\text { to the maximal } \\
\text { pain }\end{array}$ & $\begin{array}{l}\text { Unfocused, Continuous, } \\
\text { frequency = } 8 \mathrm{MHz}, \\
\mathrm{Ml}=0.7, \max \\
\text { Intensity }=152 \mathrm{~mW} / \mathrm{cm}^{2}\end{array}$ & $\begin{array}{l}\text { Heart rate, systolic } \\
\text { and diastolic blood } \\
\text { pressure, oxygen } \\
\text { saturation, numerical } \\
\text { rating scale for pain, } \\
\text { Visual Analog Mood } \\
\text { Scale }\end{array}$ & $\begin{array}{l}15 \text { s ultrasound } \\
\text { significantly improved } \\
\text { mood at } 10 \text { and } 40 \text { min } \\
\text { following stimulation }\end{array}$ & Excitatory & $\begin{array}{l}\text { Transient } \\
\text { headache } \\
\text { exacerbation } \\
\text { following } \\
\text { stimulation } \\
\text { (1 subj) }\end{array}$ \\
\hline $\begin{array}{l}\text { Monti et al. } \\
(2016)\end{array}$ & $\begin{array}{l}\text { Post-traumatic } \\
\text { disorder of } \\
\text { consciousness } \\
19 \text { days post-injury } \\
(n=1) / \text { Case report, } \\
\text { part of an ongoing } \\
\text { clinical trial }\end{array}$ & Thalamus & $\begin{array}{l}\text { Focused frequency }=650 \\
\mathrm{kHz}, \mathrm{PD}=0.5 \mathrm{~ms} \\
\mathrm{DC}=5 \%, \mathrm{PRF}=100 \mathrm{~Hz} \\
\text { Ispta }=720 \mathrm{~mW} / \mathrm{cm}^{2}\end{array}$ & $\begin{array}{l}\text { Chart review, } \\
\text { response to } \\
\text { command, and } \\
\text { reliable } \\
\text { communication (by } \\
\text { yes/no head } \\
\text { gesturing) }\end{array}$ & $\begin{array}{l}3 \text { days of ultrasound } \\
\text { treatment the patient } \\
\text { demonstrated } \\
\text { emergence from } \\
\text { minimally conscious } \\
\text { state. } 5 \text { days after } \\
\text { treatment, the patient } \\
\text { attempted to walk. }\end{array}$ & Excitatory & No \\
\hline $\begin{array}{l}\text { Beisteiner } \\
\text { et al. (2020) }\end{array}$ & $\begin{array}{l}\text { AD patients } \\
(n=35) / \text { multicenter } \\
\text { pre-post study }\end{array}$ & $\begin{array}{l}\text { AD relevant } \\
\text { brain areas } \\
\text { and the global } \\
\text { brain }\end{array}$ & $\begin{array}{l}\text { Single ultrashort ( } 3 \mu \mathrm{s} \text { ) } \\
\text { ultrasound pulses, typical } \\
\text { energy } \\
\text { levels }=0.2-0.3 \mathrm{~mJ} / \mathrm{mm}^{2} \text {, } \\
\text { PRF }=1-5 \mathrm{~Hz} \text {, maximum } \\
\text { energy flux density }=0.25 \\
\mathrm{Mj} / \mathrm{mm}^{2} \text { at } 4 \mathrm{~Hz} \text {, maximum } \\
\text { Ispta }=0.1 \mathrm{~W} / \mathrm{cm}^{2} \\
\text { maximum number of } \\
\text { pulses per } \\
\text { treatment }=6,000\end{array}$ & $\begin{array}{l}\text { EEG data recorded } \\
\text { at CP3, SEPs, } \\
\text { neuropsychological } \\
\text { tests, MRI }\end{array}$ & $\begin{array}{l}\text { TPS treatment } \\
\text { significantly improved } \\
\text { neuropsychological } \\
\text { scores, the effects last } \\
\text { up to } 3 \text { months and } \\
\text { correlates with an } \\
\text { upregulation of the } \\
\text { memory network }\end{array}$ & Excitatory & No \\
\hline $\begin{array}{l}\text { Badran et al. } \\
(2020)\end{array}$ & $\begin{array}{l}\text { Healthy subjects } \\
(n=19) / \text { double- } \\
\text { blind, } \\
\text { sham-controlled, } \\
\text { crossover study }\end{array}$ & $\begin{array}{l}\text { Right anterior } \\
\text { thalamus }\end{array}$ & $\begin{array}{l}\text { Focused, } \\
\text { frequency }=650 \mathrm{kHz}, \\
\mathrm{PD}=5 \mathrm{~ms}, \mathrm{PRF}=10 \mathrm{~Hz}, \\
\mathrm{DC}=5 \%, \mathrm{SD}=30 \mathrm{~s}, \\
\text { Ispta }=719 \text { and } \\
995 \mathrm{~W} / \mathrm{cm}^{2}\end{array}$ & $\begin{array}{l}\text { Sensory threshold, } \\
\text { sensory, pain, and } \\
\text { tolerance thresholds } \\
\text { to a thermal stimulus }\end{array}$ & $\begin{array}{l}\text { Thermal pain sensitivity } \\
\text { was significantly } \\
\text { attenuated after tFUS } \\
\text { treatment }\end{array}$ & Inhibitory & No \\
\hline
\end{tabular}

AD, Alzheimer's disease; BOLD, blood oxygenation level dependent; $D C$, duty cycle; DMN, default mode network; EMG, electromyography; ESI, electrophysiological source imaging; Ispta, the intensity of spatial-peak temporal average; M1, primary motor cortex; MEPs, motor-evoked potential; MRCP, movement-related cortical potential; MSPA, MRCP source profile amplitude; MN, median nerve; PRF, pulse repetition frequency; rIFG, right inferior frontal gyrus; S1, left primary and secondary somatosensory cortex; S2, left secondary somatosensory cortex; SEPs, somatosensory evoked potentials; SD, sonication duration; TBD, tone-burst duration; TPS, transcranial pulse stimulation; SICl, short interval intracortical inhibition; TMS, transcranial magnetic stimulation; V1, primary visual cortex; VEPS, visual evoked potentials. 
and $650 \mathrm{kHz}$ inhibited sensory evoked potentials with a spatial resolution of $\sim 2 \mathrm{~mm}$ in swine, supporting its potential use in non-invasive brain mapping. Longer ultrasound pulses delivered over prolonged periods tend to result in a more substantial and sustained decrease in neural function. The physiological effects lasted for a period of several minutes without inducing tissue heating or histological damage (Dallapiazza et al., 2018). Kim et al. (2015) reported that the application of pulsed $350 \mathrm{kHz}$ tFUS using a $5 \% \mathrm{DC}$ and Isppa intensity of $3 \mathrm{~W} / \mathrm{cm}^{2}$ to the visual cortex area suppressed the magnitude of visual evoked potentials (VEPs) in rats. Under the same conditions, higher intensity $\left(5 \mathrm{~W} / \mathrm{cm}^{2}\right)$ or DC $(8.3 \%)$ induced slight elevation in VEPs (Kim et al., 2015). Yoon et al. (2019) investigated the bimodal effects of tFUS in the modulation of the sensorimotor cortex and thalamus in an ovine model by evaluating the rate and magnitude of electrophysiological responses to a wide range of sonication parameters. The study suggests that a shorter SD $(\leq \sim 500 \mathrm{~ms})$ at a higher DC (30\%) favored excitation, and a longer SD ( $\sim 1 \mathrm{~min})$ at a lower DC $(\leq 10 \%)$ resulted in suppression. For excitation effects, the use of $15.8 \mathrm{~W} / \mathrm{cm}^{2}$ Isppa generated a higher response rate than the use of $18.2 \mathrm{~W} / \mathrm{cm}^{2}$. This study provided important evidence for the effects of varying sonication parameters on neuromodulation response (Yoon et al., 2019).

The above studies that reported excitatory and inhibitory regulation effects demonstrated the feasibility of tFUS to the clinical application of neural modulation. However, the ultrasound parameters used by different research groups are different, no two studies used consistent parameters. The rules of the neuromodulation effect corresponding to parameter changes are still unclear. Change of any one of the main ultrasound parameters may produce a change of efficacy of excitatory or inhibitory effects, with the correlation relationship is considered to be non-linear. Nevertheless, the influence of any parameters on the modulatory direction is inconclusive, and the combination of multiple parameters seems more difficult. Further research should be conducted to explore how to precisely control parameters to achieve a specific adjustment purpose.

Other evidence of inhibitory neuromodulation effects comes from research in animal models of epilepsy. An early study by Min et al. (2011) reported that low-intensity, pulsed FUS $(690 \mathrm{kHz})$ sonication suppressed the number of epileptic signal bursts and severe epileptic behavior using an acute epilepsy model in animals. Yang et al. (2020) delivered pulsed closedloop transcranial ultrasound stimulation with a frequency of $500 \mathrm{kHz}$ to the hippocampus to modulate neural oscillation and effectively inhibited the seizure of a temporal lobe epilepsy (TLE) mouse. The study of Chen et al. (2020) reported that pulsed tFUS $(500 \mathrm{kHz})$ effectively suppressed epileptic spikes in an acute epilepsy animal model and found that ultrasound pulsation interferes with neuronal activity. Zhengrong Lin et al. (2020) demonstrated that low-intensity pulsed FUS could improve the electrophysiological activities and behavioral outcomes in nonhuman primate models of epilepsy. The study also demonstrated that ultrasound suppressed abnormal epileptiform activities of neurons from human epileptic slices (Lin et al., 2020). The suppression of epileptic neuro-electric activity and the behavior of tFUS may mainly indicate inhibitory effects.
Moreover, most current animal experiments are performed using anesthetized animal models to prevent animal motion during ultrasound administration. A recently published study by Wang $X$. et al. (2021) demonstrated that the behavioral states, especially anesthesia, modulate the ultrasound stimulation-induced neural activity. The effect of pharmacological sedation on tFUS induced effects is not clear and may obfuscate the interpretation of the tFUS neuromodulation response (Jerusalem et al., 2019). Studies in awake and freely moving animals are needed. Lee et al. (2018) conducted the first study that using awake rats to evaluate the neuromodulatory efficacy of tFUS. They developed a miniature tFUS headgear with a frequency of $600 \mathrm{kHz}$, and the stimulation of motor cortical areas by their configuration elicited body movements from various areas in freely moving rats. Compared with the anesthetic rats, the stimulation in awake rats induced an increased response rate with reduced variability and shorter latency. However, the lack of measurement of electrophysiological signals in this study limited its information (Lee et al., 2018). Li et al. (2019) designed a miniature and lightweight head-mounted ultrasound stimulator that can be used in freely moving mice. When target at the primary somatosensory cortex barrel field, the device evoked head-turning behaviors and action potentials recorded in situ (Li et al., 2019). The application of stimulation in awake animals is valuable for the research on the neuromodulation effects and mechanisms of tFUS, especially for investigations that are not possible with anesthesia, such as social behavioral studies and disease models that are influenced by anesthesia (e.g., epilepsy).

\section{NEUROMODULATION IN HUMAN SUBJECTS}

The excitatory effects of tFUS were identified in healthy human subjects in 9 studies as indicated by fMRI and EEG. Six studies showed the inhibitory effects of TUS indicated by SEPs, motor induced potentials (MEPs), and intracortical facilitation (ICF). The modulated brain targets included the motor cortex, somatosensory cortex, thalamus, caudate nuclei, and visual cortex. Several studies have reported the effect of FUS stimulation on patients with chronic pain, posttraumatic disorder of consciousness, and Alzheimer's disease (AD) (Table 2).

\section{EXCITATORY MODULATION}

Studies provide evidence that FUS stimulation can activate the brain to produce sensory and motor nerve responses without any external stimulation. Three studies conducted by Lee et al. (2015) showed excitatory effects of tFUS on the human primary and secondary somatosensory cortex and visual cortex. tFUS targeting the human hand somatosensory cortex (S1) elicited somatosensory sensations with anatomical specificity up to a finger and evoked EEG potentials similar to the classical SEPs generated by median nerve stimulation (Lee et al., 2015). In another study, they reported that FUS targeting to the human visual cortex (V1) induced the perception of phosphine and 
activated a network of regions involved in visual and higher-order cognitive processes (Lee et al., 2016b). They also reported that tFUS application to the human bilateral primary somatosensory cortex (S1) and secondary somatosensory cortex (S2) elicited various tactile sensations in the targeted hand area. This study also showed the possibility of simultaneous stimulation of the S1 and S2 (proximal to each other) with ultrasound, which has not been feasible with conventional non-invasive brain stimulation approaches such as TMS or tDCS. The ability to selectively stimulate multiple human brain areas in a spatially restricted manner may offer an unprecedented opportunity to study the causal relationships between brain activity and subsequent efferent behaviors (Lee et al., 2016a). Ai et al. (2018) combined tFUS with high-field 7T fMRI in humans and evaluated its neuromodulation effect by the BOLD response. $t F U S$ stimulation targeted individual finger representations within M1 increased the activation volumes of the M1 thumb representation in a spatially restricted manner. These results provide a more detailed perspective on the spatial resolution of tFUS for neuromodulation of individual finger representations within a single gyrus reflected by the BOLD response (Leo et al., 2016; Ai et al., 2018).

FUS stimulation modulates the neural response induced by behavioral tasks and TMS-induced MEPs. Liu et al. (2021) evaluated the interference of tFUS stimulation at S1 on the performances in a mechanical vibration frequency discrimination task in a group of healthy human participants. The behavioral results indicated that low-intensity tFUS stimulation improved vibration frequency discrimination capability. EEG and electrophysiological source imaging (ESI) results revealed that tFUS improved sensory discrimination capability through exciting the targeted sensory cortex (Liu et al., 2021). The study by Gibson et al. (2018) used a diagnostic imaging ultrasound system to stimulate the motor cortex. Increased TMS-induced MEPs amplitude (34\%) was recorded up to 6 min after stimulation but disappeared 11 min later (Gibson et al., 2018). This result contrasts with the research of Legon et al., who reported tFUS inhibited MEPs induced by TMS (Legon et al., 2018b). As discussed by the authors, the different findings may be caused by stimulation parameters and other methodological factors. Yu et al. (2020) demonstrated the neuromodulatory effects of low-intensity tFUS on human voluntary movementrelated cortical potential (MRCP). Through ESI, the results showed that tFUS modulates MRCP source dynamics with high spatiotemporal resolutions and significantly increases the MRCP source profile amplitude (MSPA), and further, a high PRF enhances the MSPA outperforms a low UPRF does. This study provides the first evidence that tFUS enhances human endogenous motor cortical activities through excitatory modulation (Yu et al., 2020).

\section{INHIBITORY MODULATION}

Five studies by one research group reported the inhibitory modulation effect of tFUS targeting the primary somatosensory cortex (CP3), unilateral sensory nuclei of the thalamus, and primary motor cortex. They used similar ultrasound parameters with the $500 \mathrm{kHz}$ frequency, 36\% DC, $500 \mathrm{~ms} \mathrm{SD}$, and $1 \mathrm{kHz}$ PRF. The first study reported that tFUS targeting CP3 significantly attenuated the amplitudes of SEPs and modulated the spectral content of brain oscillations elicited by median nerve stimulation, while enhanced the somatosensory discrimination abilities of participants. Importantly, this research also showed that the influence of tFUS on brain activity can be spatially restricted within $1 \mathrm{~cm}$ (Legon et al., 2014). The following study by Mueller et al. (2014) found that tFUS preferentially affected the phase distribution of the beta band and modulated the phase rate of both beta and gamma frequencies. The third study reported that tFUS targeting the thalamus attenuated the SEPs generated in the ventrallateral nucleus and serially connected cortical regions. The study provided initial evidence that tFUS can non-invasively modulate subcortical areas of the human brain with good spatial precision and resolution (Legon et al., 2018a). The fourth study showed that tFUS inhibits the amplitude of single-pulse MEPs and attenuates intracortical facilitation, which confirms previous results that ultrasound results in effective neuronal inhibition. tFUS did not affect short interval intracortical inhibition (SICI) or reduce reaction time in a simple stimulus response task in this study (Legon et al., 2018b). The studies of Fomenko et al. (2020) reported that tFUS targeting at the motor cortex displayed inhibitory effects on cortical excitability, but the effects on SICI were inconsistent. Furthermore, other studies have reported heterogeneous effects of FUS targeting on the motor cortex, demonstrating increased cortical excitability or the amplitude of MEPs after prolonged sonication (Gibson et al., 2018; Yu et al., 2020).

Like animal studies, human studies have inconsistent conclusions about whether ultrasound modulation is exciting or inhibiting. In addition to the influence of sonication parameters, differences in detection methods also may introduce inherent variability. For example, the study of Leo et al. (2016) and Legon et al. (2018a) used similar FUS protocols (500 kHz frequency, $36 \% \mathrm{DC}$, and $1 \mathrm{kHz} \mathrm{RPF}$ ) targeting the M1 cortex demonstrated excitatory or inhibitory effect, respectively. Leo et al. (2016) reported BOLD fMRI signals were induced by tFUS, while Legon et al. (2018a) detected reduced amplitude of MEPs and intracortical facilitation. Further prospective studies are needed to elucidate region- and neuron-specific sensitivity to focused ultrasound with a wider range of parameters.

\section{CLINICAL APPLICATION}

Preliminary research has explored the role of this technology in the treatment of human brain functional diseases. In healthy subjects, Sanguinetti et al. (2020) reported two experiments that demonstrated that tFUS targeting the right inferior frontal gyrus (rIFG) enhances mood and changed the functional connectivity in networks related to emotional regulation. These results suggest that tFUS may be useful in modulating mood and emotional regulation networks (Sanguinetti et al., 2020). Badran BW conducted a controlled, double-blind study to investigate 
whether sonication targeting deep brain structures produces quantifiable antinociceptive effects in healthy adults. The study reveals that two 10 -min sessions of tFUS delivered to the right anterior thalamus produced significant antinociceptive effects in thermal pain threshold ratings, suggesting that tFUS appears to be able to focally target deep brain structures and modulate pain perceptions (Badran et al., 2020).

Four studies have provided evidence for its potential in disease treatment in patients with chronic pain, a minimally conscious state, AD and epilepsy. Hameroff et al. (2013) reported a double-blind, sham-controlled crossover study applying $8 \mathrm{MHz}$ unfocused transcranial ultrasound stimulation targeted to the posterior frontal cortex in 31 patients with chronic pain. They found improvement in subjective mood 10 and 40 min after stimulation, suggesting that ultrasound treatment can beneficially affect mental state. However, the study was limited in clinic time and unable to perform extensive psychological testing (Hameroff et al., 2013). Monti et al. (2016) published a clinical case report showed that thalamic tFUS stimulation improved the minimally conscious state in a patient after acute brain injury. An important study by Beisteiner et al. (2020) introduces a clinical sonication technique based on single ultrashort ultrasound pulses $(3 \mu \mathrm{s})$ repeated every 200-300 ms transcranial pulse stimulation (TPS), which markedly differs from others. The TPS was applied to brain regions of patients with probable $\mathrm{AD}$. The researchers found that the treatment significantly improved neuropsychological scores and upregulated corresponding memory network. This study provided comprehensive preclinical and clinical feasibility, safety, and efficacy data for TPS in the treatment of AD. Thus, widespread neuroscientific application and translation of the method to clinical therapy is encouraged (Beisteiner et al., 2020). An early research by Brinker et al. (2020) developed a laboratorybuilt experimental device platform and successfully delivered repetitive low-intensity tFUS across the hippocampus in seizure onset zones of patients with drug-resistant TLE. Further study is still ongoing for investigating the effects of tFUS therapeutic neuromodulation in the patients with TLE (Brinker et al., 2020). Overall, to move tFUS forward as a potential therapy for brain diseases, more researches in patients are needed to explore targeting, dosing, and parameter optimization modes.

\section{EVIDENCE FOR MECHANISMS}

The precise mechanisms of neuromodulation with ultrasound are unclear. Studies have explored the mechanism for the neuromodulation effect of tFUS from the perspective of brain networks, neural cells, and molecules (Table 1). The effect of ultrasound neuromodulation on brain network connections has been reported in researches using macaques and rats. Verhagen et al. (2019) reported that $40 \mathrm{~s}$ of ultrasound stimulation in macaques modulated the brain activation for more than $1 \mathrm{~h}$ and the ultrasound displays offline and sustained impact on the connectional fingerprint of stimulated brain regions. The study of Folloni et al. (2019) demonstrated that a tFUS protocol impacts activity in the subcortical brain structure of the amygdala and deep cortical region of the anterior cingulate cortex in macaques.
The stimulation suppressed the connectivity of the targeted brain area to its network (Folloni et al., 2019). The study of Fouragnan et al. (2019) investigated how representations of counterfactual choices are held in memory and guide behavior in macaque monkeys. tFUS was used to focally alter the neural activity to examine the causal importance of the anterior cingulate cortex (ACC) for behavior. They found that tFUS significantly impaired translation of counterfactual choice values into actual behavioral change and changed the activity and connectivity maps of the ACC (Fouragnan et al., 2019). The study of Zhang et al. (2021) reported that FUS reduced the network connections of epilepsy circuits and change the structure of the brain network at the whole-brain level. The adjustment effect of tFUS on neural network connection may be the mechanism of its repeated application to improve brain diseases.

At the cellular level of neurons, two studies reported bimodal neural modulation effects of tFUS in macaques. The study of Wattiez et al. (2017) assessed the neuromodulatory effects of tFUS in awake behaving monkeys by recording discharge activity from a brain region (supplementary eye field) reciprocally connected with the stimulated region (frontal eye field). They demonstrated that stimulation in the visual cortex significantly changed the activity of $40 \%$ of neurons in the recorded region. Half of the neurons showed transiently increased activity, and the other half showed decreased activity. In this study, the ultrasonic effect was quantified based on the direct measurement of the intensity of the modulation induced on a single neuron in a freely performing animal. In particular, the study suggests that different neurons respond differently to tFUS stimuli and indicates further parametric studies should pay attention to the regulation of neural activity at the cell level (Wattiez et al., 2017). Yang et al. (2021) reported that medium amplitude tFUS (425 kPa free-field at $250 \mathrm{kHz}$ ) in the macaque brain modulated the activity of neurons at the target in dual directions (excitation and suppression). This simultaneous excitatory and suppressive neuromodulation may be mediated by activation of large excitatory pyramidal and small inhibitory interneurons, respectively. This study first examined the neuromodulation effects of FUS at the whole-brain level and the ability of concurrent FUS and MRI to evaluate causal interactions between functional circuits and neuron-class selectivity (Yang et al., 2021).

Several studies provided evidence for the mechanism of the neuromodulation effect at the molecular level. Recent investigations on the interactions between sound pressure waves and brain tissue suggest that ultrasound primarily exerts its modulatory effects through mechanical action on cell membranes, notably affecting ion channel gating (Kubanek et al., 2016). Liang et al. (2020) explored the efficacy and mechanisms of tFUS in treating pain caused by soft tissue injury. Low-intensity focused ultrasound relieved pain, and the mechanism could be attributed to decreasing the release of analgesic substances from the nerve and reducing local inflammatory factors (Liang et al., 2020). Na Pang et al. (2021) demonstrated that transcranial ultrasound stimulation was effective in modulating the learning behaviors of mice and the expression of apoptosis, oxidative stress, and inflammation. Xu et al. (2020) demonstrated that low-intensity ultrasound is able to stimulate DA release and 
helps to regenerate dopaminergic neurons in a mouse model of Parkinson's disease (PD). Huang et al. (2019) reported that noninvasive low-intensity pulsed ultrasound stimulation improved $c$-fos expression and reduced the incidence rate $(p<0.05)$ and length of primary cilia $(p<0.01)$ of neurons in the rat CA1 hippocampus. Bobola et al. (2020) reported that acutely applied tFUS activated microglia to colocalize with $A \beta$ plaques in a mouse model of $\mathrm{AD}$, and 5 days of tFUS cleared almost $50 \%$ of the $\mathrm{A} \beta$ plaque. The study of Chen et al. (2020) suggested that pulsed tFUS exposure effectively suppresses epileptic spikes in an acute epilepsy animal model and revealed that ultrasound pulsation affects the PI3K-Akt-mTOR pathway, which might be the molecular mechanism. These studies only provide preliminary clues, and more studies are needed in the future.

\section{SAFETY OF TRANSCRANIAL FOCUSED ULTRASOUND}

Currently, ultrasound for neuromodulation in humans generally follows the guidelines of the FDA for adult cephalic applications. Legon et al. (2020) qualitatively evaluated minor adverse events in seven independent experiments using different ultrasound protocols for human neuromodulation. The intensity (Isppa) used in these studies ranged from 11.56 to $17.12 \mathrm{~W} / \mathrm{cm}^{2}$ that is considerably lower than FDA thresholds for ultrasound diagnostics. The parameter of Ispta, which is defined as the Isppa multiplied by the duty factor, in these studies was above FDA thresholds for diagnostics. They found that none of the participants experienced serious adverse effects, and 7/64 reported mild to moderate symptoms probably related to ultrasound treatment. The symptoms include neck pain, attention problems, muscle twitches, and anxiety. They concluded that the symptom rate and type induced by tFUS are similar to other forms of human non-invasive neuromodulation, such as TMS and tDCS, these two have been used as safe forms of human neuromodulation. Despite the causation role of ultrasound has not been defined, the findings suggest limiting the intensity used in future ultrasound experiments for neuromodulation (Legon et al., 2020). Gaur et al. (2020) examined a range of experimental parameters, including the number of focal spot locations, the number of FUS bursts applied to each spot, the timing between FUS sessions, and applied acoustic intensity, to investigate the safety of FUS neuromodulation. The in situ intensities were $9.5 \mathrm{~W} / \mathrm{cm}^{2}$ in macaques and $6.7 \mathrm{~W} / \mathrm{cm}^{2}$ in sheep, similar to and slightly higher than previously reported Ispta values of up to $4.4 \mathrm{~W} / \mathrm{cm}^{2}$ in humans. Repeated FUS neuromodulation at various intensity levels for multiple days did not cause histologic damage. The study suggesting that the neuromodulation protocols evaluated

\section{REFERENCES}

Ai, L., Bansal, P., Mueller, J. K., and Legon, W. (2018). Effects of transcranial focused ultrasound on human primary motor cortex using 7T fMRI: a pilot study. BMC Neurosci. 19:56. doi: 10.1186/s12868-018-0456-6 do not cause tissue damage and provide important information for the safety profiles of FUS neuromodulation (Gaur et al., 2020).

\section{DISCUSSION}

Overall, tFUS is a promising non-invasive brain stimulation technology. The current findings in both animal and human studies reported both the excitatory and inhibitory modulatory effects of tFUS on brain activity. These findings confirmed the application prospects of this technology in the treatment of brain functional diseases. However, the current research does not clarify the correlation among the roles of the stimulus parameters in excitatory or inhibitory modulatory effects. The excitatory and inhibitory effects shown in current research are mostly on a macro level, and it is not clear whether these effects are derived from inhibitory or excitatory neuronal activity. Inhibitory effects may come from the excitement of inhibitory neurons or the inhibition of excitatory neurons, and the opposite is also possible. The physiological state (active or resting) of neurons in the stimulated area and its connected areas and how these neurons interact during the modulation process could also influence the results. Like clinical trials, animal experiments have been conducted in normal animals and disease model animals, the targets include the sensory cortex, motor cortex, and deep nuclei such as the thalamus. The range of ultrasonic parameters used in animal studies were similar to that in clinical trials. Due to the differences in skull size and geometry of the brain, the parameters from tFUS used in animals are less likely to be translated to humans. Further animal studies should focus on the change law of excitation or inhibition effect with the fine change of parameters, and to further reveal the mechanism of regulation effect at the nerve conduction, cellular and molecular levels. The safety profile, effectiveness, and finer device parameters in humans in either healthy or diseased conditions need further research.

\section{AUTHOR CONTRIBUTIONS}

TZ drafted this report. SH, CL, NP, and YW revised and expanded. All authors contributed to the article and approved the submitted version.

\section{FUNDING}

We acknowledge the support by the National Natural Science Foundation of China (No. 82071483) and the Natural Science Foundation of Beijing (No. 7212048) within the funding program Open Access Publishing.

Badran, B. W., Caulfield, K. A., Stomberg-Firestein, S., Summers, P. M., Dowdle, L. T., Savoca, M., et al. (2020). Sonication of the anterior thalamus with MRIGuided transcranial focused ultrasound (tFUS) alters pain thresholds in healthy adults: a double-blind, sham-controlled study. Brain Stimul. 13, 1805-1812. doi: 10.1016/j.brs.2020.10.007 
Baek, H., Pahk, K. J., Kim, M. J., Youn, I., and Kim, H. (2018). Modulation of cerebellar cortical plasticity using low-intensity focused ultrasound for poststroke sensorimotor function recovery. Neurorehabil. Neural Repair 32, 777-787. doi: 10.1177/1545968318790022

Beisteiner, R., Matt, E., Fan, C., Baldysiak, H., Schonfeld, M., Philippi Novak, T., et al. (2020). Transcranial pulse stimulation with ultrasound in Alzheimer's disease-a new navigated focal brain therapy. Adv. Sci. 7:1902583. doi: 10.1002/ advs. 201902583

Bobola, M. S., Chen, L., Ezeokeke, C. K., Olmstead, T. A., Nguyen, C., Sahota, A., et al. (2020). Transcranial focused ultrasound, pulsed at $40 \mathrm{~Hz}$, activates microglia acutely and reduces Abeta load chronically, as demonstrated in vivo. Brain Stimul. 13, 1014-1023. doi: 10.1016/j.brs.2020.03.016

Brinker, S. T., Preiswerk, F., White, P. J., Mariano, T. Y., McDannold, N. J., and Bubrick, E. J. (2020). Focused ultrasound platform for investigating therapeutic neuromodulation across the human hippocampus. Ultrasound Med. Biol. 46, 1270-1274. doi: 10.1016/j.ultrasmedbio.2020.01.007

Bystritsky, A., Korb, A. S., Douglas, P. K., Cohen, M. S., Melega, W. P., Mulgaonkar, A. P., et al. (2011). A review of low-intensity focused ultrasound pulsation. Brain Stimul. 4, 125-136. doi: 10.1016/j.brs.2011.03.007

Chen, S. G., Tsai, C. H., Lin, C. J., Lee, C. C., Yu, H. Y., Hsieh, T. H., et al. (2020). Transcranial focused ultrasound pulsation suppresses pentylenetetrazol induced epilepsy in vivo. Brain Stimul. 13, 35-46. doi: 10.1016/j.brs.2019. 09.011

Dallapiazza, R. F., Timbie, K. F., Holmberg, S., Gatesman, J., Lopes, M. B., Price, R. J., et al. (2018). Noninvasive neuromodulation and thalamic mapping with low-intensity focused ultrasound. J. Neurosurg. 128, 875-884. doi: 10.3171/ 2016.11.jns 16976

Darrow, D. P., O’Brien, P., Richner, T. J., Netoff, T. I., and Ebbini, E. S. (2019). Reversible neuroinhibition by focused ultrasound is mediated by a thermal mechanism. Brain Stimul. 12, 1439-1447. doi: 10.1016/j.brs.2019.07.015

Fini, M., and Tyler, W. J. (2017). Transcranial focused ultrasound: a new tool for non-invasive neuromodulation. Int. Rev. Psychiatry 29, 168-177. doi: 10.1080/ 09540261.2017.1302924

Fisher, J. A. N., and Gumenchuk, I. (2018). Low-intensity focused ultrasound alters the latency and spatial patterns of sensory-evoked cortical responses in vivo. J. Neural Eng. 15:e035004. doi: 10.1088/1741-2552/aaaee1

Folloni, D., Verhagen, L., Mars, R. B., Fouragnan, E., Constans, C., Aubry, J. F., et al. (2019). Manipulation of subcortical and deep cortical activity in the primate brain using transcranial focused ultrasound stimulation. Neuron 101, 1109.e5-1116.e5. doi: 10.1016/j.neuron.2019.01.019

Fomenko, A., Chen, K. S., Nankoo, J. F., Saravanamuttu, J., Wang, Y., El-Baba, M., et al. (2020). Systematic examination of low-intensity ultrasound parameters on human motor cortex excitability and behavior. eLife 9:e54497. doi: 10.7554/ eLife. 54497

Fouragnan, E. F., Chau, B. K. H., Folloni, D., Kolling, N., Verhagen, L., KleinFlugge, M., et al. (2019). The macaque anterior cingulate cortex translates counterfactual choice value into actual behavioral change. Nat. Neurosci. 22, 797-808. doi: 10.1038/s41593-019-0375-6

Gaur, P., Casey, K. M., Kubanek, J., Li, N., Mohammadjavadi, M., Saenz, Y., et al. (2020). Histologic safety of transcranial focused ultrasound neuromodulation and magnetic resonance acoustic radiation force imaging in rhesus macaques and sheep. Brain Stimul. 13, 804-814. doi: 10.1016/j.brs.2020.02.017

Gibson, B. C., Sanguinetti, J. L., Badran, B. W., Yu, A. B., Klein, E. P., Abbott, C. C., et al. (2018). Increased excitability induced in the primary motor cortex by transcranial ultrasound stimulation. Front. Neurol. 9:1007. doi: 10.3389/fneur. 2018.01007

Hameroff, S., Trakas, M., Duffield, C., Annabi, E., Gerace, M. B., Boyle, P., et al. (2013). Transcranial ultrasound (TUS) effects on mental states: a pilot study. Brain Stimul. 6, 409-415. doi: 10.1016/j.brs.2012.05.002

Hoy, K. E., and Fitzgerald, P. B. (2010). Brain stimulation in psychiatry and its effects on cognition. Nat. Rev. Neurol. 6, 267-275. doi: 10.1038/nrneurol.2 010.30

Huang, X., Lin, Z., Meng, L., Wang, K., Liu, X., Zhou, W., et al. (2019). Non-invasive low-intensity pulsed ultrasound modulates primary cilia of rat hippocampal neurons. Ultrasound Med. Biol. 45, 1274-1283. doi: 10.1016/j. ultrasmedbio.2018.12.012

Jerusalem, A., Al-Rekabi, Z., Chen, H., Ercole, A., Malboubi, M., Tamayo-Elizalde, M., et al. (2019). Electrophysiological-mechanical coupling in the neuronal membrane and its role in ultrasound neuromodulation and general anaesthesia. Acta Biomater. 97, 116-140. doi: 10.1016/j.actbio.2019.07.041

Kim, H., Chiu, A., Lee, S. D., Fischer, K., and Yoo, S. S. (2014). Focused ultrasound-mediated non-invasive brain stimulation: examination of sonication parameters. Brain Stimul. 7, 748-756. doi: 10.1016/j.brs.2014.06.011

Kim, H., Park, M. Y., Lee, S. D., Lee, W., Chiu, A., and Yoo, S. S. (2015). Suppression of EEG visual-evoked potentials in rats through neuromodulatory focused ultrasound. Neuroreport 26, 211-215. doi: 10.1097/wnr.0000000000000330

Krishna, V., Sammartino, F., and Rezai, A. (2018). A review of the current therapies, challenges, and future directions of transcranial focused ultrasound technology: advances in diagnosis and treatment. JAMA Neurol. 75, 246-254. doi: 10.1001/jamaneurol.2017.3129

Kubanek, J. (2018). Neuromodulation with transcranial focused ultrasound. Neurosurg. Focus 44:E14. doi: 10.3171/2017.11.focus17621

Kubanek, J., Shi, J., Marsh, J., Chen, D., Deng, C., and Cui, J. (2016). Ultrasound modulates ion channel currents. Sci. Rep. 6:24170. doi: 10.1038/srep24170

Lee, W., Kim, H. C., Jung, Y., Chung, Y. A., Song, I. U., Lee, J. H., et al. (2016b). Transcranial focused ultrasound stimulation of human primary visual cortex. Sci. Rep. 6:34026. doi: 10.1038/srep34026

Lee, W., Chung, Y. A., Jung, Y., Song, I. U., and Yoo, S. S. (2016a). Simultaneous stimulation of the human primary and secondary somatosensory cortices using transcranial focused ultrasound. J. Ther. Ultras. 4:31. doi: 10.1186/s40349-0160076-5

Lee, W., Croce, P., Margolin, R. W., Cammalleri, A., Yoon, K., and Yoo, S. S. (2018). Transcranial focused ultrasound stimulation of motor cortical areas in freely-moving awake rats. BMC Neurosci. 19:57. doi: 10.1186/s12868-0180459-3

Lee, W., Kim, H., Jung, Y., Song, I. U., Chung, Y. A., and Yoo, S. S. (2015). Image-guided transcranial focused ultrasound stimulates human primary somatosensory cortex. Sci. Rep. 5:8743. doi: 10.1038/srep08743

Legon, W., Adams, S., Bansal, P., Patel, P. D., Hobbs, L., Ai, L., et al. (2020). A retrospective qualitative report of symptoms and safety from transcranial focused ultrasound for neuromodulation in humans. Sci. Rep. 10:5573. doi: 10.1038/s41598-020-62265-8

Legon, W., Bansal, P., Tyshynsky, R., Ai, L., and Mueller, J. K. (2018b). Transcranial focused ultrasound neuromodulation of the human primary motor cortex. Sci. Rep. 8:10007. doi: 10.1038/s41598-018-28320-1

Legon, W., Ai, L., Bansal, P., and Mueller, J. K. (2018a). Neuromodulation with single-element transcranial focused ultrasound in human thalamus. Hum. Brain Mapp. 39, 1995-2006. doi: 10.1002/hbm.23981

Legon, W., Sato, T. F., Opitz, A., Mueller, J., Barbour, A., Williams, A., et al. (2014). Transcranial focused ultrasound modulates the activity of primary somatosensory cortex in humans. Nat. Neurosci. 17, 322-329. doi: 10.1038/nn. 3620

Leo, A., Mueller, J. K., Grant, A., Eryaman, Y., and Wynn, L. (2016). Transcranial focused ultrasound for BOLD fMRI signal modulation in humans. IEEE Eng. Med. Biol. Soc. 2016, 1758-1761. doi: 10.1109/EMBC.2016.7591057

Li, G., Qiu, W., Zhang, Z., Jiang, Q., Su, M., Cai, R., et al. (2019). Noninvasive ultrasonic neuromodulation in freely moving mice. IEEE Trans. Biomed. Eng. 66, 217-224. doi: 10.1109/TBME.2018.2821201

Liang, D., Chen, J., Zhou, W., Chen, J., Chen, W., and Wang, Y. (2020). Alleviation effects and mechanisms of low-intensity focused ultrasound on pain triggered by soft tissue injury. J. Ultrasound Med. 39, 997-1005. doi: 10.1002/jum.15185

Lin, Z., Meng, L., Zou, J., Zhou, W., Huang, X., Xue, S., et al. (2020). Non-invasive ultrasonic neuromodulation of neuronal excitability for treatment of epilepsy. Theranostics 10, 5514-5526. doi: 10.7150/thno.40520

Liu, C., Yu, K., Niu, X., and He, B. (2021). Transcranial focused ultrasound enhances sensory discrimination capability through somatosensory cortical excitation. Ultras. Med. Biol. 47, 1356-1366. doi: 10.1016/j.ultrasmedbio.2021. 01.025

Mehic, E., Xu, J. M., Caler, C. J., Coulson, N. K., Moritz, C. T., and Mourad, P. D. (2014). Increased anatomical specificity of neuromodulation via modulated focused ultrasound. PLoS One 9:e86939. doi: 10.1371/journal.pone.0086939

Min, B. K., Bystritsky, A., Jung, K. I., Fischer, K., Zhang, Y., Maeng, L. S., et al. (2011). Focused ultrasound-mediated suppression of chemically-induced acute epileptic EEG activity. BMC Neurosci. 12:23. doi: 10.1186/1471-2202-12-23

Mohammadjavadi, M., Ye, P. P., Xia, A., Brown, J., Popelka, G., and Pauly, K. B. (2019). Elimination of peripheral auditory pathway activation does not affect 
motor responses from ultrasound neuromodulation. Brain Stimul. 12, 901-910. doi: 10.1016/j.brs.2019.03.005

Monti, M. M., Schnakers, C., Korb, A. S., Bystritsky, A., and Vespa, P. M. (2016). Non-invasive ultrasonic thalamic stimulation in disorders of consciousness after severe brain injury: a first-in-man report. Brain Stimul. 9, 940-941. doi: 10.1016/j.brs.2016.07.008

Moore, M. E., Loft, J. M., Clegern, W. C., and Wisor, J. P. (2015). Manipulating neuronal activity in the mouse brain with ultrasound: a comparison with optogenetic activation of the cerebral cortex. Neurosci. Lett. 604, 183-187. doi: 10.1016/j.neulet.2015.07.024

Mueller, J., Legon, W., Opitz, A., Sato, T. F., and Tyler, W. J. (2014). Transcranial focused ultrasound modulates intrinsic and evoked EEG dynamics. Brain Stimul. 7, 900-908. doi: 10.1016/j.brs.2014.08.008

Pang, N., Huang, X., Zhou, H., Xia, X., Liu, X., Wang, Y., et al. (2021). Transcranial ultrasound stimulation of hypothalamus in aging mice. IEEE Trans. Ultrason. Ferroelectr. Freq. Control 68, 29-37. doi: 10.1109/TUFFC.2020.2968479

Rahimpour, S., Kiyani, M., Hodges, S. E., and Turner, D. A. (2021). Deep brain stimulation and electromagnetic interference. Clin. Neurol. Neurosurg. 203:106577. doi: 10.1016/j.clineuro.2021.106577

Romanella, S. M., Sprugnoli, G., Ruffini, G., Seyedmadani, K., Rossi, S., and Santarnecchi, E. (2020). Noninvasive brain stimulation \& space exploration: opportunities and challenges. Neurosci. Biobehav. Rev. 119, 294-319. doi: 10. 1016/j.neubiorev.2020.09.005

Sanguinetti, J. L., Hameroff, S., Smith, E. E., Sato, T., Daft, C. M. W., Tyler, W. J., et al. (2020). Transcranial focused ultrasound to the right prefrontal cortex improves mood and alters functional connectivity in humans. Front. Hum. Neurosci. 14:52. doi: 10.3389/fnhum.2020.00052

Verhagen, L., Gallea, C., Folloni, D., Constans, C., Jensen, D. E., Ahnine, H., et al. (2019). Offline impact of transcranial focused ultrasound on cortical activation in primates. eLife 8:e40541. doi: 10.7554/eLife.40541

Wang, X., Zhang, Y., Zhang, K., and Yuan, Y. (2021). Influence of behavioral state on the neuromodulatory effect of low-intensity transcranial ultrasound stimulation on hippocampal CA1 in mouse. Neuroimage 241:118441. doi: 10. 1016/j.neuroimage.2021.118441

Wang, Y., Zhan, G., Cai, Z., Jiao, B., Zhao, Y., Li, S., et al. (2021). Vagus nerve stimulation in brain diseases: therapeutic applications and biological mechanisms. Neurosci. Biobehav. Rev. 127, 37-53. doi: 10.1016/j.neubiorev. 2021.04.018

Wattiez, N., Constans, C., Deffieux, T., Daye, P. M., Tanter, M., Aubry, J. F., et al. (2017). Transcranial ultrasonic stimulation modulates single-neuron discharge in macaques performing an antisaccade task. Brain Stimul. 10, 1024-1031. doi: 10.1016/j.brs.2017.07.007

Xu, T., Lu, X., Peng, D., Wang, G., Chen, C., Liu, W., et al. (2020). Ultrasonic stimulation of the brain to enhance the release of dopamine - A potential novel treatment for Parkinson's disease. Ultrason. Sonochem. 63:104955. doi: 10.1016/j.ultsonch.2019.104955

Yang, H., Yuan, Y., Wang, X., and Li, X. (2020). Closed-loop transcranial ultrasound stimulation for real-time non-invasive neuromodulation in vivo. Front. Neurosci. 14:445. doi: 10.3389/fnins.2020.00445

Yang, P. F., Phipps, M. A., Jonathan, S., Newton, A. T., Byun, N., Gore, J. C., et al. (2021). Bidirectional and state-dependent modulation of brain activity by transcranial focused ultrasound in non-human primates. Brain Stimul. 14, 261-272. doi: 10.1016/j.brs.2021.01.006

Yoo, S. S., Kim, H., Min, B. K., Franck, E., and Park, S. (2011). Transcranial focused ultrasound to the thalamus alters anesthesia time in rats. Neuroreport 22, 783-787. doi: 10.1097/WNR.0b013e32834b2957

Yoon, K., Lee, W., Lee, J. E., Xu, L., Croce, P., Foley, L., et al. (2019). Effects of sonication parameters on transcranial focused ultrasound brain stimulation in an ovine model. PLoS One 14:e0224311. doi: 10.1371/journal.pone.0224311

Yu, K., Liu, C., Niu, X., and He, B. (2020). Transcranial focused ultrasound neuromodulation of voluntary movement-related cortical activity in humans. IEEE Trans. BioMed. Eng. 68, 1923-1931. doi: 10.1109/TBME.2020.3030892

Yu, K., Sohrabpour, A., and He, B. (2016). Electrophysiological source imaging of brain networks perturbed by low-intensity transcranial focused ultrasound. IEEE Trans. Biomed. Eng. 63, 1787-1794. doi: 10.1109/tbme.2016.2591924

Yuan, Y., Wang, Z., Liu, M., and Shoham, S. (2020). Cortical hemodynamic responses induced by low-intensity transcranial ultrasound stimulation of mouse cortex. Neuroimage 211:116597. doi: 10.1016/j.neuroimage.2020.116597

Zhang, M., Li, B., Lv, X., Liu, S., Liu, Y., Tang, R., et al. (2021). Low-intensity focused ultrasound-mediated attenuation of acute seizure activity based on EEG brain functional connectivity. Brain Sci. 11:711. doi: 10.3390/brainsci11060711

Conflict of Interest: The authors declare that the research was conducted in the absence of any commercial or financial relationships that could be construed as a potential conflict of interest.

Publisher's Note: All claims expressed in this article are solely those of the authors and do not necessarily represent those of their affiliated organizations, or those of the publisher, the editors and the reviewers. Any product that may be evaluated in this article, or claim that may be made by its manufacturer, is not guaranteed or endorsed by the publisher.

Copyright (c) 2021 Zhang, Pan, Wang, Liu and Hu. This is an open-access article distributed under the terms of the Creative Commons Attribution License (CC BY). The use, distribution or reproduction in other forums is permitted, provided the original author(s) and the copyright owner(s) are credited and that the original publication in this journal is cited, in accordance with accepted academic practice. No use, distribution or reproduction is permitted which does not comply with these terms. 